\title{
The importance of diagnostic and therapeutic efficacy of th1/th2 cytokines in a case report of a 47-year-old lady, who was misdiagnosed with the traditional medical methods
}

\author{
Toliopoulos $\mathrm{IK}^{1 *}$, Zoitas $\mathrm{G}^{2}$ and Kostikidis $\mathrm{M}^{\mathbf{1}}$ \\ ${ }^{1}$ Konstantinion Research Center of Molecular Medicine and Biotechnology, Thessaloniki, Greece \\ ${ }^{2}$ Bioharmony Center, Athens, Greece
}

\begin{abstract}
Background: We introduce the importance of diagnostic evaluation of 13 cytokine network (TH1/TH2 family), which refers to a patient who was misdiagnosed from a doctor of internal medicine. The flow cytometry technology proved the clinical-laboratorial outcome and the targeted therapeutic approach for the specific patient.

Case presentation: A 47-year-old lady complained about different symptoms in nose and head and misdiagnosed for acute rhinitis and sinusitis, where she received the wrong drugs (antistaminic), and her deterioration was the result with acute body weakness, abdominal pains, and in the area of face. Our center with the specific investigation of 13 cytokines found out specific causes of the symptoms and suggested specific treatments (high dosage of vitamin C and probiotics) to regulate the physiology of the patient. The symptoms of the patient started retrieving in the first 15 days of the treatment and this improvement was proved by the retesting of the 13 cytokines of TH1/TH2.

Conclusion: The individual specific targeted test for cytokines TH1/TH2 is important to be performed and evaluated ONLY by specialists that know how to diagnose and explain the immunologic role of cytokines in the extracellular space (matrix). This evaluation helps significantly in major diagnostic and therapeutic procedure in the independent physiology status of the patient.
\end{abstract}

\section{Background}

The diagnostic targeted testing approach of the evaluation of 13 cytokines Th1/Th2 in patient's serum is one exceptional immunological test, which contributes significantly in testing the immunological status of the patient. The abnormal cytokine levels are the major cause for the imbalance of immune system [1]. Also, this testing gives the potential to the therapist to regulate the physiology of the patient and to restore the general health. Cytokines, including interleukins, interferons, tumor necrosis factors, and chemokines, have a variety of pro- and anti-inflammatory effects in the body through a number of biochemical pathways and interactions [2]. However, particular cutoffs of cytokines as biomarkers for disease processes have not been well studied, and therefore most clinical doctors can't evaluate their diagnostic significance in their daily practice [3]. In this case the misdiagnosis of a clinical doctor of internal medicine to a 47-year-old guided our centers to investigate her case and led to significant diagnostic approach with the flow cytometric technology in the Th1/th2 testing.

\section{Case presentation}

A 47-year-old female was diagnosed for allergic rhinitis from specialized physician due to the symptoms (acute body weakness, abdominal pains, and in the area of face) that the patient mentioned without diagnostic testing. Then she was administered with 2 known antihistamine drugs. Later, the following tests were advised by the same doctor: ultrasound of thyroid, laboratorial tests such as general blood test, urea, creatinine, LDH, CPK, anti-nuclear antibodies (ANA), P-ANCA, C-ANCA, vitamin B2, IgE, culture for ureaplasma and mucoplasma, microscopic analysis of vaginal liquid, and the thyroid tests as TSH, T3, T4, anti-TPO, anti-TG.

All the above tests were normal except the white blood test were $12150 / \mu \mathrm{l}$ and the antibodies against the thyroid gland which was antiTG $364 \mathrm{IU} / \mathrm{ml}$. Surely, these results don't justify the diagnosis of allergic rhinitis and the worse result was that the antihistamine drugs caused side effects such as fatigue and exhaustion.

On the other hand, our team suggested immediately quitting these drugs and suggested the 13 cytokines immunological test of TH1/TH2 Cells. The technology used for the measurements in human serum of the 13 cytokines was performed by the BD cytometric bead array [4]. The test showed that inteleukin 5 (IL-5) was quite increased with the value $2550 \mathrm{pg} / \mathrm{ml}$ Table 1 . The rest of cytokines were at normal values. The increase of IL-5 in the serum according to the international scientific bibliography is expressed in patients that

${ }^{*}$ Correspondence to: Ioannis John $\mathrm{K}$ Toliopoulos, $\mathrm{PhD}$, President of Konstantinion Research Center of Molecular Medicine and Biotechnology, Kilkisiou 20 str. 54639 Thessaloniki, Greece, E-mail: johntolio@hotmail.com

Key words: cytokines, TH1/TH2, flow cytometry, interleukins

Received: January 02, 2019; Accepted: January 28, 2019; Published: January 31, 2019 
Toliopoulos IK (2019) The importance of diagnostic and therapeutic efficacy of th1/th2 cytokines in a case report of a 47-year-old lady, who was misdiagnosed with the traditional medical methods

Table 1. Levels of 13 cytokines in 47-year-old lady without any treatment

\begin{tabular}{|c|c|c|c|c|c|c|c|c|c|c|c|c|}
\hline $\begin{array}{l}\text { IL-16 result } \\
\text { in } \mathrm{pg} / \mathrm{ml}\end{array}$ & $\begin{array}{l}\text { IFN- } \gamma \text { result } \\
\text { in } \mathrm{pg} / \mathrm{ml}\end{array}$ & $\begin{array}{c}\text { IL-2 result in } \\
\mathrm{pg} / \mathrm{ml}\end{array}$ & $\begin{array}{l}\text { IL-10 result } \\
\text { in } \mathrm{pg} / \mathrm{ml}\end{array}$ & $\begin{array}{c}\text { IL-8 result in } \\
\mathrm{pg} / \mathrm{ml}\end{array}$ & $\begin{array}{c}\text { IL-6 result in } \\
\mathrm{pg} / \mathrm{ml}\end{array}$ & $\begin{array}{c}\text { IL-4 result in } \\
\mathrm{pg} / \mathrm{ml}\end{array}$ & $\begin{array}{c}\text { IL-5 result in } \\
\mathrm{pg} / \mathrm{ml}\end{array}$ & $\begin{array}{l}\text { IL-1 } \beta \text { result } \\
\text { in } \mathrm{pg} / \mathrm{ml}\end{array}$ & $\begin{array}{l}\text { TNF } \alpha \text { result } \\
\text { in pg/ml }\end{array}$ & $\begin{array}{l}\text { IL-12 result } \\
\text { in } \mathrm{pg} / \mathrm{ml}\end{array}$ & $\begin{array}{c}\text { IL-17A } \\
\text { result in } \\
\mathrm{pg} / \mathrm{ml}\end{array}$ & $\begin{array}{l}\text { IL-23 result } \\
\text { in } \mathrm{pg} / \mathrm{ml}\end{array}$ \\
\hline 2 & 1 & 2 & 2 & 1 & 2550 & 5 & 1 & 2 & 1 & 5 & 2 & 5 \\
\hline
\end{tabular}

Table 2. Levels of 13 cytokines in 47-year-old lady after a monthly treatment with vitamin C and probiotics

\begin{tabular}{|c|c|c|c|c|c|c|c|c|c|c|c|c|}
\hline $\begin{array}{l}\text { IL-16 result } \\
\text { in } \mathrm{pg} / \mathrm{ml}\end{array}$ & $\begin{array}{l}\text { IFN- } \gamma \text { result } \\
\text { in } \mathrm{pg} / \mathrm{ml}\end{array}$ & $\begin{array}{c}\text { IL-2 result in } \\
\mathrm{pg} / \mathrm{ml}\end{array}$ & $\begin{array}{l}\text { IL-10 result } \\
\text { in } \mathrm{pg} / \mathrm{ml}\end{array}$ & $\begin{array}{c}\text { IL-8 result in } \\
\mathrm{pg} / \mathrm{ml}\end{array}$ & $\begin{array}{c}\text { IL-6 result in } \\
\mathrm{pg} / \mathrm{ml}\end{array}$ & $\begin{array}{c}\text { IL-4 result in } \\
\mathrm{pg} / \mathrm{ml}\end{array}$ & $\begin{array}{c}\text { IL-5 result in } \\
\mathrm{pg} / \mathrm{ml}\end{array}$ & $\begin{array}{l}\text { IL-1 } 1 \beta \text { result } \\
\text { in } \mathrm{pg} / \mathrm{ml}\end{array}$ & $\begin{array}{l}\text { TNF } \alpha \text { result } \\
\text { in } \mathrm{pg} / \mathrm{ml}\end{array}$ & $\begin{array}{l}\text { IL-12 result } \\
\text { in } \mathrm{pg} / \mathrm{ml}\end{array}$ & $\begin{array}{c}\mathrm{IL}-17 \mathrm{~A} \\
\text { result in } \\
\mathrm{pg} / \mathrm{ml}\end{array}$ & $\begin{array}{l}\text { IL-23 result } \\
\text { in } \mathrm{pg} / \mathrm{ml}\end{array}$ \\
\hline 2 & 1 & 2 & 2 & 1 & 64 & 5 & 1 & 2 & 1 & 5 & 2 & 5 \\
\hline
\end{tabular}

suffer from intestinal parasitosis, have abdominal cramp pains and have recurrent respiratory infections [5-8].

Based on this diagnostic value, the recommendation for the patient for one month was high dosages of Vitamin C (Lamberts, UK) (3gram per day in powder,), and Probiotics (Probioflor Plus, Swiss formula) for the regulation of the gut flora and the battle against the parasites. At the end of the month after the above therapeutic approach, retesting was performed in the 13 cytokines Th1/Th2, IgE, and a general blood test. Interleukin 5 was significantly reduced at $64 \mathrm{pg} / \mathrm{ml}$ Table 2, IgE was negative and the white blood cells were regulated at normal range of $6150 / \mu$, while the patient was totally relieved from symptoms.

\section{Discussion}

The diagnostic approach of the 13 cytokines Th1/Th2 that was applied in this case contributed effectively to the appropriate treatment. Vitamin C is a well-known antioxidant that increases the immune system. Also, it has been reported to shift immune responses toward Th1, and to decrease inflammatory cell numbers in brochoalveolar lavage fluid, and moderate reduction of perivascular and peribronchiolar inflammatory cell infiltration, which is correlated with increased levels of IL-5 [9]. IL-5 is the most important cytokine in the transformation and development of eosinophils, and acts as an "eosinophil activator". One of the significant causes of the increase in the amount of eosinophils in blood is parasitic diseases. Toxiallergic effects of certain parasites on the host's organism lead to an increase especially in eosinophil numbers. It is suggested therefore that the function of IL-5 and eosinophils is to protect against repeated exposure to gastrointestinal parasites [10,11]. Mast cells from healthy controls don't produce IL-5, but mast cells from patients with intestinal inflammatory disease could release a relatively large amount of IL-5[. IL-5 induced by parasites may play a role in causing Irritable Bowel Syndrome (IBD), which seems to be the major issue in this study case of the 47-year-old lady [12]. On the other hand, Probioflor plus increased in intestinal flora as studies report that probiotics decrease the levels of IL-5, which was observed in this study case in table 2 [13]. Also, IL-5 is a Th2 cytokine and Turner et al. reported that $\mathrm{Th} 2$ response is important in protection against and destroying the parasites [14] and Pit et al found that levels of IL-5 were induced by intestinal helminthes [15]. In addition, probiotics in general improve in balancing the Th1/Th2 immune system $[16,17]$. The purpose of this study case is to stress and emphasize the potential role of cytokines in the daily clinical medical practice because it has been reported that they play a pivotal role in the pathogenesis of autoimmune diseases and major diseases such as myocarditis, Thyroiditis, Uveitis, Arthritis, Encephalomyelitis, Lupus, depression, and other [18]. However, due to the limited number of studies investigating effectiveness of particular cytokine cutoffs as diagnostic tools, further studies must be conducted to narrow diagnostic ranges. Such a narrowing of diagnostic ranges will facilitate confirmation or rejection of diagnoses suggested by other clinical features to ultimately improve patient outcomes [18].

\section{Conclusion}

It has to be stressed that the individual specific targeted test for cytokines TH1/TH2 is important to be performed and evaluated ONLY by specialists that know how to diagnose and explain the immunologic role of cytokines in the extracellular space (matrix) because by this way the reason of the disease can be easily investigated so complete individualized therapy can be achieved for full relief of symptoms. Also, it has to be noted that the balance for lymphocytes TH1/TH2 is very important in human immunology and physiology and the directions towards either side leads to autoimmune diseases, carcinogenesis, chronic allergies, asthma, or others. Furthermore, the expression of each cytokine in the matrix has been measured and evaluated the last years and can potentially lead the doctor in full diagnostic value according to the international literature and obviously this testing procedure is necessary for preventive and therapeutic approach in for most diseases.

\section{References}

1. Yazdanbakhsh M, van den Biggelaar A, Maizels RM (2001) Th2 responses without atopy: immunoregulation in chronic helminth infections and reduced allergic disease. Trends Immunol 22: 372-377.

2. He SH (2004) Key role of mast cells and their major secretory products in inflammatory bowel disease. World J Gastroenterol 10: 309-318.

3. Solis ACO, Marques AH, Dominguez WV, Prado EBA, Pannuti CM, et al. (2016) Evaluation of periodontitis in hospital outpatients with major depressive disorder. A focus on gingival and circulating cytokines. Brain Behav Immun 53: 49-53. [Crossref]

4. Dinarrelo CA (1997) Role of pro- and anti-inflammatory cytokines during inflammation:experimental and clinical findings. J Biol Regul Homeost Agents.11: 91103.

5. Su DL, Lu ZM, Shen MN, Li X, Sun LY (2012) Roles of pro- and anti-inflammatory cytokines in the pathogenesis of SLE. J Biomed Biotechnol 2012: 347141. [Crossref]

6. E Morgan, R Varro, H Sepulveda, et al.(2004) .Cytometric bead array: a multiplexed assay platform with applications in various areas of biology. Clin Immunol 110: 252266.

7. Garside P, Kennedy MW, Wakelin D, Lawrence CE (2000) Immunopathology of intestinal helminth infection. Parasite Immunol 22: 605-612. [Crossref]

8. Maizels RM, Yazdanbakhsh M (2003) Immune regulation by helminth parasites: cellular and molecular mechanisms. Nat Rev Immunol 3: 733-744.

9. Schwarze J, Gelfand GW (2002) Respiratory viral infections as promoters of allergic sensitization and asthma in animal models. European Respiratory Journal 19: 341-349.

10. Lee DR (2011) A case of eosinophilic gastrointestinal disorders presenting with chronic diarrhea and abdominal pain. Korean J Fam Med 32: 257-262. [Crossref]

11. Jeong YJ, Kim JH, Kang JS, Lee WJ, Hwang YI (2010) Mega-dose vitamin C attenuated lung inflammation in mouse asthma model. Anat Cell Biol 43: 294-302. [Crossref]

12. Garside P, Kennedy MW, Wakelin D, Lawrence CE (2000) Immunopathology of intestinal helminth infection. Parasite Immunol 22: 605-612. 
Toliopoulos IK (2019) The importance of diagnostic and therapeutic efficacy of th1/th2 cytokines in a case report of a 47-year-old lady, who was misdiagnosed with the traditional medical methods

13. Wang IK, Wu YY, Yang YF, Ting IW, Lin CC, et al. (2015) The effect of probiotics on serum levels of cytokine and endotoxin in peritoneal dialysis patients: a randomised, double-blind, placebo-controlled trial. Benef Microbes 6: 423-430. [Crossref]

14. Turner JD, Faulkner H, Kamgno J, Cormont F, Van Snick J, Else KJ, et al. (2003) Th2 cytokines are associated with reduced worm burdens in a human intestinal helminth infection. J Infect Dis 188: 1768-1775.

15. Pit DS, Polderman AM, Schulz-Key H, Soboslay PT (2000) Prenatal immune priming with helminth infections: parasite-specific cellular reactivity and Th1 and Th2 cytokine responses in neonates. Allergy 55: 732-739.
16. Takahashi N, Kitazawa H, Iwabuchi N, Xiao JZ, Miyaji K, et al. (2006) Ora administration of an immunostimulatory DNA sequence from Bifidobacterium longum improves Th1/Th2 balance in a murine model. Biosci Biotechnol Biochem 70: 20132017.

17. Kara J. Filbery, Mali Camberis, Jodie Chandler et al. (2018) Intestinal helminth infection promotes IL-5- and CD4+ T cell-dependent immunity in the lung against migrating parasites. Mucosal Immunol. Nov 6.

18. Monastero RN, Pentyala S1,2,3,4 (2017) Cytokines as Biomarkers and Their Respective Clinical Cutoff Levels. Int J Inflam : 4309485. [Crossref]

Copyright: $@ 2019$ Toliopoulos IK. This is an open-access article distributed under the terms of the Creative Commons Attribution License, which permits unrestricted use, distribution, and reproduction in any medium, provided the original author and source are credited. 